\author{
Olebogeng LITHEKO \\ Lochner MARAIS \\ Joris HOEKSTRA \\ Jan CLOETE \\ Molefi LENKA
}

\title{
Black middle-income housing and asset building in Mangaung, South Africa
}

\begin{abstract}
Asset-building policies are used worldwide to reduce state welfare commitments. In the Global South, including South Africa, asset-based housing development is thought to help reduce poverty. This study investigated asset building and homeownership in a sample of South Africa's emerging black middle class. Interviews with 244 black middle-class households in Mangaung revealed asset value creation and heavy dependence on mortgage finance. Levels of mortgage default were low, although households with recently secured mortgages struggled to pay them off. We found little evidence that property-owning is helping these households to move out of poverty. Their ability to afford mortgage loans appeared to be directly related to their own efforts and human capital. Very few had considered downsizing as an option, possibly because ownership of a house has social value, for passing on to the next generation. Asset building was still in its early stages and, because these households had been denied equal opportunities and barred from homeownership by the apartheid regime, very few intergenerational transfers had yet occurred.
\end{abstract}

Keywords: asset building, black middle class, housing, inheritance, poverty alleviation

\section{Introduction}

Asset-based welfare has become common practice worldwide because governments want households to become less dependent on them by being more self-reliant. Asset-based welfare programmes support large-scale housing privatisation and homeownership-support projects in the Global North. In the Global South, land-titling programmes dominate assetbased development programmes. Many policy makers view land titling as the best way to lift the poor out of poverty. In South Africa, the Housing Subsidy Programme pursues the same objective. Since 2004 there has been an increased emphasis on the role of property in reducing poverty. Current policy envisages that the poor will use these housing subsidies to climb the housing ladder, trade in the property sector and use their houses to help them escape from poverty (Department of Human Settlements, 2014).

Although South African housing policy has always focused on the lower-income groups, a secondary objective has been to deal with the housing problems of the emerging black middle class, particularly the lower black middle class. This secondary focus on a higher-income group was evident in the way the policy was originally structured. In 1994, a monthly income of between R2,500 and R3,500 ( $\mathrm{R}$ - South African Rand) would have attracted a subsidy of $\mathrm{R} 5,000$, and below R800 a subsidy of R15,000. Effectively, therefore, higher incomes meant smaller subsidies. Higher-income households therefore had to supplement the subsidy with 
mortgage finance. The post-apartheid government has consequently attempted to simplify the process of accessing mortgage finance.

However, despite the policy's focus on lower-middle-class housing, research has focused largely on housing for the poor. A search of the housing literature of the first 20 years after democracy (1994-2014) found only two studies of the lower-middle-class household (Tomlinson, 1997, 2007). But recently there has been a revival of academic interest in this topic (Marais \& Cloete, 2015, 2017; Lemanski, 2017; Marais et al., 2018). Generally, attention has been devoted to the rising black middle class (Southall, 2016), and a special edition of Development Southern Africa (Volume 32, Issue 1, 2015) was dedicated to this topic. But despite this upswing in the literature, we still do not know much about black middle-income use of houses as assets. In this paper we attempt to improve understanding of how the black middle class use housing within the broader asset-building approach. Taking into account the historical deprivation of black people as regards socio-economic development and housing, we investigated three black middle class housing issues: the role of housing in asset generation, the extent to which housing helps reduce poverty, and the risks associated with asset building.

The Population Registration Act of 1950 classified South Africans in terms of race: black (then referred to as "native"), coloured and white, and later Indian, as a separate group. The Group Areas Act meant suburbs were racially designated. Both Acts were repealed in 1991. We concede that, more than two decades into democracy, many households cannot be defined by these historical racial categories. We use the term "black" in this paper as used in the historical context. Democracy in South Africa has brought economic and social freedom to black households, giving rise to a black middle class. For convenience, we use the term "middle class" in this paper, while acknowledging that it is difficult to define "middle class" and that the definition should go beyond income to include access to good education and housing.

\section{Review of asset-based welfare literature}

\subsection{Asset-based welfare in the Global North}

The idea of asset-based welfare is that people with sufficient assets can organise their own welfare. Asset-based policies provide needy households with both the means and the opportunities to accumulate assets and thus have greater control over their livelihoods. Assetbased welfare policies are particularly important in Europe, where trust funds are common practice. According to Sherraden (2003), asset-based policies have more profound implications for individuals than do welfare policies that focus on income transfers. Assetbased strategies empower people to act strategically and proactively. For instance, they may use their assets to invest in training in order to avoid possible redundancy.

The asset-based welfare literature is mainly concerned with financial assets and does not discuss housing in depth. However, in the field of housing, a completely new strand of literature on asset-based welfare has emerged, particularly since the global financial crisis. This strand borrows key ideas from the asset-based welfare literature and adapts them to the specific capital-intensive and investment-oriented features of the housing field (see Prabhakar, 2018, for further details). 
In the literature dealing with asset-based welfare in housing, housing assets are often seen as a lever for welfare state restructuring (Groves et al., 2007; Malpass, 2008; Doling \& Ronald, 2010), the general idea being that homeowners can use their accumulated housing assets as a personal safety net. These assets can act as a supplement to (or even a substitute for) other state welfare provisions. Governments may therefore use principles of housing-related assetbased welfare to justify a reduction in their spending in key areas of the welfare state, notably pension and healthcare provision (Hoekstra, 2010). This may make sense on a macro level but can lead to inequalities on a micro level (Elsinga \& Hoekstra, 2015). For example, inequality can be created between a homeowner and a tenant (who does not accumulate housing assets) or between a homeowner living in a "good" location and another living in a deprived neighbourhood. Intergenerational transfers may also reproduce inequality in housing asset holding across generations (Deng et al., 2017).

The asset-based welfare research on housing tends to be conceptual and theoretical. There is a dearth of research on the practical aspects of releasing housing equity (the difference between the market value and the outstanding debt on the house) and the strategies of households wanting to release housing equity, particularly after a crisis. A notable exception is a recently published research report for the European Union produced by a consortium of European universities (Al-Umaray, 2018). Based on focus-group research, this report provides insight into the strategies and perceptions of older homeowners in six European countries: the United Kingdom, Germany, the Netherlands, Ireland, Italy and Hungary. The report says housing equity can be released in five different ways: selling the house and buying a smaller one (downsizing), selling the house and moving to a rental house, selling the house and then renting it back (sale and leaseback), staying in the house and using a financial product to extract the housing equity, and letting part of the house.

In most countries, downsizing is the option preferred by older homeowners when they want to release housing equity. This option allows households to extract housing equity while continuing to be homeowners (homeownership being highly valued in many countries). However, there are caveats: downsizing forces people to leave their current house, which some may find difficult, and they may struggle to find an affordable alternative. And in many countries, houses or apartments that older people may find both suitable and attractive (for example, situated on the ground floor, close to facilities) are in short supply. The second option, selling the house and moving to a rental house, is a good way to release a large amount of housing equity at any given time. However, on a macro level it may also lead to high and rising housing costs for those releasing their assets, as they will have to pay rent. In contrast to the costs of owning a house, rents tend to increase over time. In addition, renting is stigmatised in some countries (for example in Italy and Ireland). On the other hand, in countries with well-developed rental markets (for example Germany and the Netherlands) many older homeowners consider this option to be a serious alternative. In the third option, sale and leaseback, the homeowner sells the house to a commercial company and then rents it back at a market-related price. This puts the homeowner in a position to release a large amount of equity while staying in the house and getting rid of maintenance obligations. In practice, however, the conditions of the sale and leaseback option are often not very advantageous. The prices that are paid for these houses are often considerably lower than market prices while the commercial rents tend to be high.

The fourth option, using a financial product to release housing equity, is the housing equityrelease strategy that has attracted most attention in the literature. The most commonly used equity-release products are reversed mortgages and home-reversion schemes. In a reversed 
mortgage, older homeowners take out an extra loan on their house (paid out in a lump sum or in monthly payments) that needs neither monthly loan repayments nor monthly interest payments. Interest due is added to the total amount of the loan. The loan is only repaid when the house is sold, after the homeowner has died or moved to institutional care. Though reversed mortgages - also referred to as lifetime mortgages - are common in the United Kingdom (the most developed European market for equity-release products), they also feature in a number of other countries like Italy, the Netherlands and Ireland. A second financial product that allows older homeowners to release housing equity is the homereversion scheme in terms of which the homeowner sells all or part of the property to a financial institution that will pay a lump sum for it. This lump sum is considerably lower than the market value but the seller (the homeowner) has the lifelong right to remain in the house. When the property is eventually sold after the homeowner has died or moved to institutional care, the financial institution will receive a sum of money equivalent to the value of the house or part of the house that it owns. Home-reversion plans are the most common equity-release product in Germany but they feature less prominently in the rest of Europe. Although there is increasing interest in financial equity-release products, consumers tend to view them with suspicion and distrust. Not only are many of these products complex but the financial sector has also generally lacked confidence in them since the global financial crisis. Finally, homeowners can let part of the house to increase their income (an option that, strictly speaking, has little to do with equity release). Though it has the disadvantage of possible loss of privacy, this option is increasingly popular in cities with tight housing markets and plenty of potential for letting tourist accommodation (known as "AirBnB").

\subsection{Asset-based welfare in the Global South}

In the Global South, asset-based welfare is often associated with the work done by De Soto (2000). He pinpointed lack of titling as the main reason why the poor have not been able to release the inherent value of their properties. Lack of titling not only prevents the poor from accessing housing finance, it also prevents them from trading their properties. De Soto's solution lay in formalising informal tenure (by providing title deeds). Land titling has since become a common policy in developing countries. De Soto's ideas did not, however, escape criticism (Gilbert, 2002; Royston, 2006; Payne et al., 2008). Among other things, he was criticised for assuming that the poor prefer to borrow from financial institutions, for oversimplifying reality, for a lack of theoretical depth and for producing little empirical evidence to support his thinking.

Moser's work $(1998,2006)$ launched a second body of asset-building literature. Her work built on research by Sen (1992) and by Nussbaum (2003), both of whom tried to deeconomise development thinking by introducing the idea of capabilities. In practice, this led to the livelihoods approach, which contributed to the idea of asset-accumulation for the poor. Moser (1998: 14) says an asset-based approach focuses on identifying "what the poor have, rather than what they do not have". She defines assets as "a stock of financial, human, natural or social resources that can be acquired, developed, improved and transferred across generations. It generates flows or consumption, as well as additional stock" (2006: 9). Moser (2006) applies Bourdieu's (1986) notion of capitals (one of the first researchers to use these terms) in her research, identifying five types: physical capital (factories, equipment, infrastructure and other productive resources owned by individuals, the business sector or the country); financial capital (financial resources such as savings and credit); human capital (investments in education, skills and health); social capital (an intangible asset defined as the rules, norms, obligations, reciprocity and trust embedded in social relations, social structures 
and institutional arrangements); and natural capital: (environmental assets such as soil, air, forests, minerals, water and wetlands). The identification and application of these assets have laid the foundation for an asset-based development approach and have moreover emphasised the relationship between assets rather than focusing solely on assets. The original development practitioners applied the livelihoods approach in rural settings. By the late 1990s, the livelihoods approach and asset-based development had also gained an urban foothold (Rakodi, 1999).

\subsection{Asset-based welfare, housing and the black middle class in South Africa}

The notion of asset-based development has featured in post-apartheid policy since 1994. It was apparent in the emphasis on homeownership and the structure of the housing subsidy. But asset-based welfare rose to prominence only with the introduction of "Breaking New Ground: A Comprehensive Plan for the Development of Sustainable Human Settlement" (Department of Housing, 2004). Breaking New Ground introduced terms like housing assets and climbing the housing ladder and emphasised the importance of the secondary housing market.

In its programme theory, the Department of Human Settlements (2014) acknowledges a number of problems that hamper asset building: racially skewed participation in the property market, biased distribution of resources and wealth, high levels of poverty and unemployment, and limited investment by the private sector in low-income areas. Two further institutional factors also cause problems: low-income earners' inadequate understanding of the housing market, and municipalities' inability to include new properties developed by means of the Housing Subsidy Programme in their rates rolls. Irrespective of these factors, the programme theory envisages that both subsidy-stock housing and old-stock housing will grow in value, that the property market will incorporate stock, that low-income housing will enter the rates roll and that all of these factors will help the poor to increase their share of the property market and move up the housing ladder.

There is a large body of work that either supports or is related to asset building and it mostly deals with low-income households. Because homeownership was not available to black people under apartheid, some researchers have chosen to refer to its availability now as "restorative justice" (Gunter, 2013). Black urban homeownership again became available in the mid-1980s, having been banned by the apartheid government since 1948. Since 1994, the post-apartheid political and economic dispensation has been providing equal opportunities to the black population. Homeownership and the easing of access to housing finance have been among the factors that have helped to produce a black middle class. The post-apartheid government has introduced initiatives to make housing finance more accessible. These include the 1994 Record of Understanding, which aimed to provide 150,000 mortgage loans to the lower middle class; the 1996 National Housing Finance Corporation, which created a state-owned enterprise to promote housing finance access; the 2003 Financial Sector Charter, signed between government and the banks, which provided for an additional 350,000 mortgages for lower-middle-income households; and the 2010 restructuring of the Finance Linked Individual Subsidy Programme, which provides mortgage finance in addition to a large state subsidy.

One attribute of middle-class households is that they hold assets (Southall, 2016). The main house is often the most prominent asset that households transfer between generations in the modern capitalist system (Piketty, 2014). Black households' historical inability either to 
accumulate assets (because of restrictions on homeownership) or to transfer them to the next generation means that their asset ownership (mortgage bonds, houses, shares, etc.) is much smaller than that of white households (South African Institute of Race Relations, 2012). In 2011 the net private asset ownership per capita for black South Africans was R73,712, while that for whites was nearly 13 times higher at R952,511 (South African Institute of Race Relations, 2012). The historical deprivation created by apartheid means that "today's black middle class has had to start from scratch" and the post-apartheid black middle class is "genuinely new and ... largely a product of post-1994 government policies" (Southall, 2016, pp. 165-166). Musyoka (2015) confirms that the black middle class's asset building is largely facilitated by its own efforts. Inheritance plays only a small part. The most important contributing factor to asset building among black middle-class households is the human capital provided by education (Southall, 2016).

Two further points to note are the importance of homeownership for asset building and the potential for residential desegregation of middle-class households since the repeal of the Group Areas Act in 1991. The literature shows that homeownership has become an important component of being middle class (Crankshaw, 2012). In a case study of young black middleclass people, Krige (2015: 114) found that homeownership was "a decisive threshold ... in the process of 'growing up' and 'moving up"' and boosted a person's social status. New economic opportunities have also allowed middle-class families to jump the racial divide and settle in former white suburbs (Harrison \& Zack, 2014). Although affordability is key to this decision, Donaldson et al. (2013) argue that the decision to move is complicated and not only about affordability. Many black middle-class households who have moved to the former white suburbs maintain their social networks in the townships (Southall, 2016).

\section{Methods and study area}

This is an exploratory study, based on a cross-sectional questionnaire survey in Mangaung, one of eight metropolitan municipalities in South Africa. Its main city is Bloemfontein and its historically black township is also called Mangaung. Mangaung Metro also includes Botshabelo and Thaba Nchu, a former "homeland" town. Despite its status as a metropolitan area, Mangaung has few international economic links and largely serves its regional hinterland.

The survey comprised 244 household interviews, the interviewee in each case being the person who knew the household finances. We used a systematic sampling method and sampled erven from cadastral information on available maps. We had a refusal rate of $12.5 \%$, the highest having been in Mandela View, Race Way Park and Vista Park. This also meant that these households had the lowest percentage of completed interviews. We interviewed middle-income households who owned houses they had bought on the open market. We spread our sample over eight suburbs (see Figure 1) occupied mainly by black households (see Table 1). As we wished to focus on the less affluent end of the black middle class, we excluded black middle-class households living in the formerly white suburbs of Bloemfontein. We mostly used descriptive statistics 


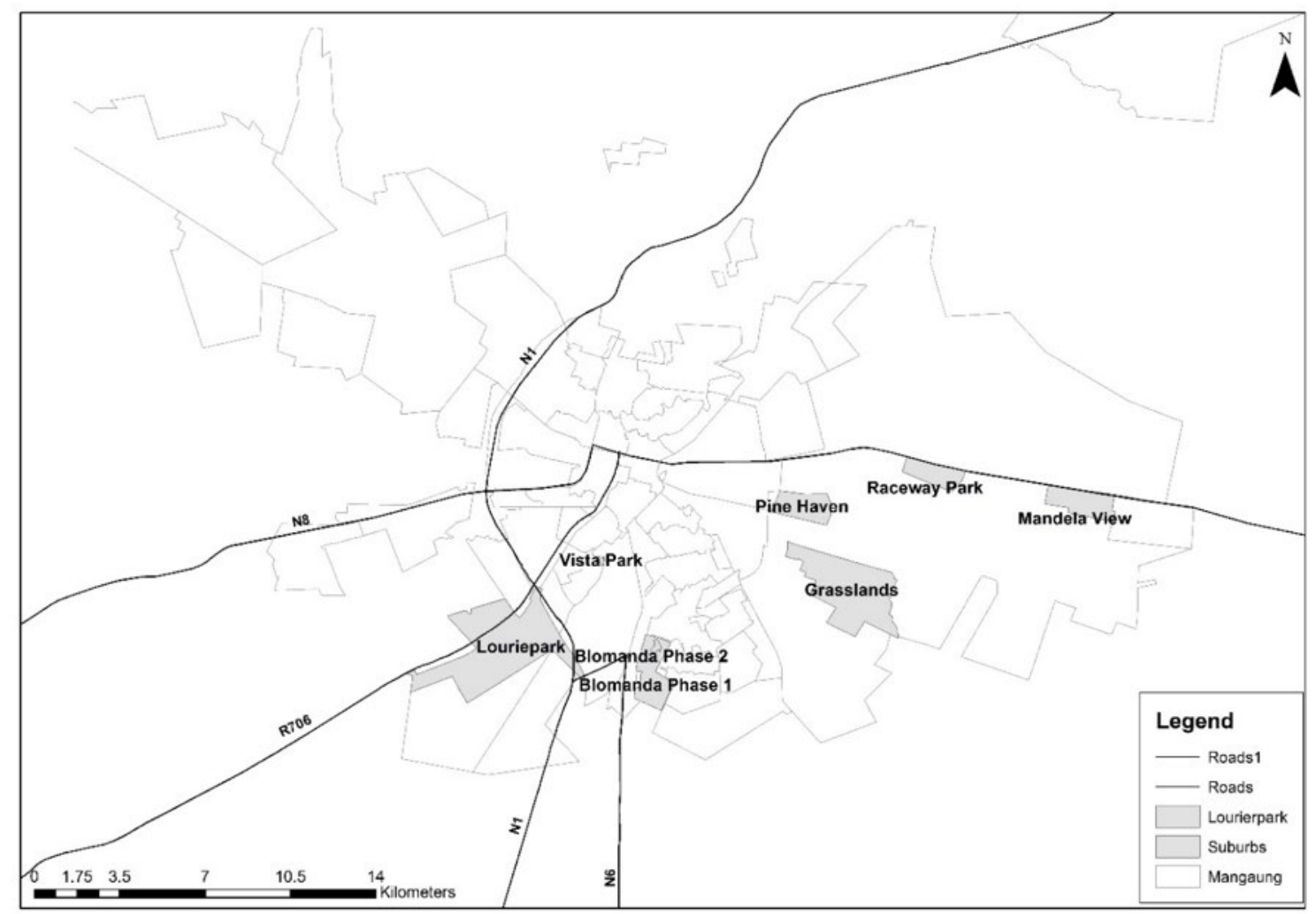

Figure 1: Location of case study areas in Mangaung Metropolitan Municipality (source: Marais et al., 2018).

Table 1: Samples per suburb in Mangaung

\begin{tabular}{|c|c|c|c|c|}
\hline \multirow[t]{2}{*}{ Suburb } & \multirow{2}{*}{$\begin{array}{r}\text { Estimated } \\
\text { no. of } \\
\text { houses }\end{array}$} & \multicolumn{2}{|c|}{ Questionnaires completed } & \multirow{2}{*}{$\begin{array}{r}\text { \% of pop. white } \\
\text { (2011 census) }\end{array}$} \\
\hline & & no. & $\%$ & \\
\hline Bloemanda Phase 1 & 5,594 & 40 & 16.4 & 0.3 \\
\hline Bloemanda Phase 2 & & 28 & 11.5 & 0.1 \\
\hline Grasslands & 10,399 & 46 & 18.9 & 0.1 \\
\hline Lourier Park & 876 & 38 & 15.6 & 0.7 \\
\hline Mandela View & 281 & 24 & 9.8 & 1.7 \\
\hline Pine Haven & 500 & 25 & 10.2 & Unable to determine \\
\hline Raceway Park & 250 & 22 & 9.0 & Unable to determine \\
\hline Vista Park & 305 & 21 & 8.6 & Unable to determine \\
\hline Total & 18,205 & 244 & 100.0 & \\
\hline
\end{tabular}

Source: StatsSA (2013).

The oldest of these eight suburbs is Bloemanda Phase 1, established in 1985, in the historically black group area as planned under apartheid. Bloemanda Phase 2 was added to this area in response to the increased demand for housing by the growing black middle class. In the mid-1980s the apartheid government abolished influx control and replaced it with orderly urbanisation. Bloemanda Phase 2 gave black households their first chance of homeownership and is typical of housing developments established since 1990. Grasslands, located next to the historically black township, was established in the early 1990s. Lourier Park, originally developed as a lower-income white suburb, was desegregated in 1991 when the government repealed the Group Areas Act. Raceway Park, Mandela View and Pine Haven, located east of the original black township of Mangaung, were developed by the private sector in the past 15 years. Vista Park, established in 2010 in one of the municipality's recent restructuring zones, is a good example of infill development. 


\section{The black middle class and assets in Mangaung}

\subsection{Households' asset profile}

Homeownership and housing being so important to the black middle class, there is a danger they may be tempted to overinvest in their housing. This would make them vulnerable to the vicissitudes of the housing market. Table 2 shows that the current housing value of the households in our sample amounts to nearly $53 \%$ of their total asset value as estimated by our respondents. This high percentage points to heavy dependence specifically on the housing asset in their asset portfolio. These households are thus vulnerable to house price shocks and those with new mortgages are vulnerable to interest rate hikes. It is striking that only about $37 \%$ of the households have a pension fund or a provident fund, amounting to $31 \%$ of asset value for all households. This means that the households without these assets are even more dependent on their housing assets. Just over a quarter of the respondents said that a member of their household had life insurance, worth on average $14 \%$ of the total asset value, and available only upon the decease of the insured. The literature on asset building emphasises the importance of savings for education. Only 5.3\% of the sample had savings schemes for education. Only $2 \%$ owned a business and not even 1\% owned shares. Overall, our data indicate an overemphasis on the housing asset, making these households vulnerable to shocks in the housing system.

Table 2: Assets profile of black middle-class households in Mangaung ( $n=244)$.

\begin{tabular}{|c|c|c|c|c|c|c|}
\hline Asset & $\begin{array}{r}\text { Number of } \\
\text { households } \\
\text { with } \\
\text { specific } \\
\text { assets }\end{array}$ & $\begin{array}{r}\% \text { of } \\
\text { households } \\
\text { with } \\
\text { specific } \\
\text { assets }\end{array}$ & $\begin{array}{r}\% \text { of } \\
\text { households } \\
\text { with more } \\
\text { than one of } \\
\text { these specific } \\
\text { assets }\end{array}$ & $\begin{array}{r}\text { Average asset } \\
\text { value for } \\
\text { those who } \\
\text { have a } \\
\text { specific asset } \\
\text { (in South } \\
\text { African rand) }\end{array}$ & $\begin{array}{r}\text { Average } \\
\text { value for all } \\
\text { respondents } \\
\text { (in South } \\
\text { African } \\
\text { rand) }\end{array}$ & $\begin{array}{c}\% \text { of } \\
\text { total } \\
\text { asset } \\
\text { value }\end{array}$ \\
\hline Pension fund & 64 & 26.3 & 10.3 & 808,099 & 212,833 & 20.5 \\
\hline Retirement annuity & 25 & 10.3 & 2.9 & $1,039,499$ & 106,944 & 10.3 \\
\hline Savings in the bank & 36 & 14.8 & 3.7 & 73,555 & 10,897 & 1.0 \\
\hline $\begin{array}{l}\text { Life insurance policy } \\
\text { Savings for }\end{array}$ & 63 & 25.9 & 13.2 & 579,473 & 150,234 & 14.4 \\
\hline education & 13 & 5.3 & 0.8 & 63,426 & 3,393 & 0.3 \\
\hline Shares & 2 & 0.8 & 0.8 & 173,466 & 1,428 & 0.1 \\
\hline Other property & 1 & 0.4 & 0.4 & 118,571 & 488 & 0.0 \\
\hline Business ownership & 5 & 2.1 & 0 & 180,600 & 3,716 & 0.4 \\
\hline Other investments & 5 & 2.1 & 0 & 17,200 & 354 & 0.0 \\
\hline $\begin{array}{l}\text { Current housing } \\
\text { value }\end{array}$ & 244 & 100 & - & 549,815 & 549,815 & 52.9 \\
\hline Total & & & & $3,603,704$ & $1,040,101$ & 100.0 \\
\hline
\end{tabular}

Source: Author's survey.

\subsection{Mortgage finance}

The sample had generally been able to build housing assets by obtaining a mortgage, as $84 \%$ of the households had a mortgage. Table 3 shows the amounts currently owed on the mortgages. It also shows the following trends: the houses are worth much more than when they were purchased, the outstanding amount owed on mortgages is smaller than the amount originally borrowed to purchase the houses (true also of those in the second section of the 
table, which shows only those who have who have an amount currently owing on mortgages), and generally good progress has been made in paying off the mortgages.

Table 3: Key indicators of housing and mortgage value, in South African rand $(n=244)$.

\begin{tabular}{lr}
\hline Indicator & Value \\
\hline All respondents (with no mortgage, or a paid-up or current mortgage) & \\
Original value of house when bought & 299,373 \\
2015 value of original house & 453,559 \\
Current value estimated by owner & 549,815 \\
Original amount of mortgage & 308,022 \\
Current amount of mortgage & 217,808 \\
Only respondents with current mortgages & \\
Original value of house when bought & 307,559 \\
2015 value of original house & 431,926 \\
Current value estimated by owner & 576,305 \\
Original amount of mortgage & 308,023 \\
Current amount of mortgage & $* 303,487$ \\
Original house value as \% of 2015 value & 71.2 \\
Original house value as \% of house value estimated by owner & 53.4 \\
Original mortgage amount as \% of original house value & 100.2 \\
Current mortgage amount as \% of 2015 house value & 71.3 \\
Current mortgage amount as \% of house value estimated by owner & 53.5 \\
Current mortgage amount as \% of original mortgage amount & 98.5 \\
\hline Soure: own
\end{tabular}

Source: own survey

Notes: Of the total of 244 houses, $84 \%$ were bought by means of a mortgage.

* The fact that the current amount of the mortgage here is higher than the original amount could indicate remortgaging or that some owners are struggling to repay their mortgage.

We investigated whether the growth in the value of our sample's housing assets had beaten inflation (between 1991 and 2015 annual inflation in SA was 7.1\%). In line with international trends, house prices rose sharply in South Africa between 2000 and 2007. Figure 2 compares the purchase price of our sample's housing assets with the 2015 value (adjusted for inflation but based on the original price). The figure highlights two important points. First, despite some minor deviations, the original purchase price and the original amount of the mortgage largely correspond. This indicates just how dependent our sample are on a mortgage. Of our sample of homeowners, $84 \%$ were mortgagors $(65 \%$ of properties in South Africa are bond free according to BusinessTech, 2015). Second, the relationship between the purchase price, adjusted for inflation, and the value estimated by the owner indicates that in peak years (2001 and 2008) owners generally tended to undervalue their houses. In general, the owners' estimates are marginally higher than the purchase prices (in 2015 values). This indicates that they have generally failed to sell their house at an inflation-beating price. In the South African housing market as a whole, however, house prices outstripped inflation by a wide margin between 2000 and 2007. 


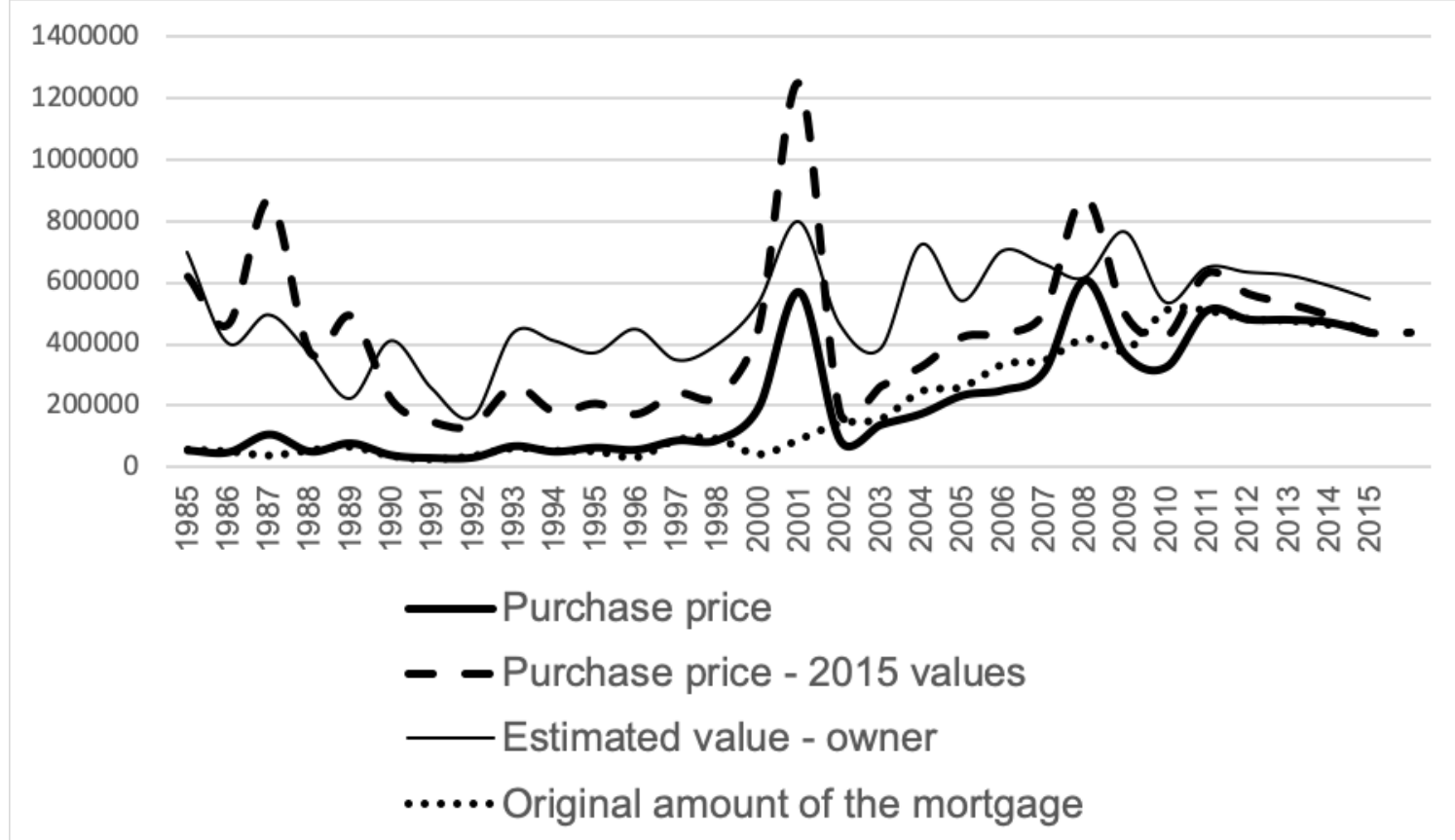

Figure 2: Key aspects of asset value of houses owned, 1985-2015 (source: Author's survey).

The real value of the housing asset also depends on the homeowners' ability to repay the mortgage on time. Figure 3 shows the original mortgage amount in the years in which the respondents bought their houses as a percentage of their current mortgage amount. As could be expected, the figure shows an increase in the percentage between 1988 and 2015, and since 2012 it has been more than $100 \%$, which could indicate that homeowners who have recently acquired a mortgage are struggling to repay them. However, we found very little evidence of this. Our evidence shows that very few respondents have defaulted on their mortgages. Only six respondents $(2.5 \%)$ reported that they had missed a monthly instalment, a percentage that is somewhat lower than the national figure of about $3 \%$ being in arrears for three months (National Credit Regulator, 2016). This low percentage could be because some respondents did not admit to having defaulted. Reasons given for having defaulted included financial problems such as having lost a job and financial commitments such as car repairs. One respondent said he did not know he had to deposit money to repay the mortgage. 


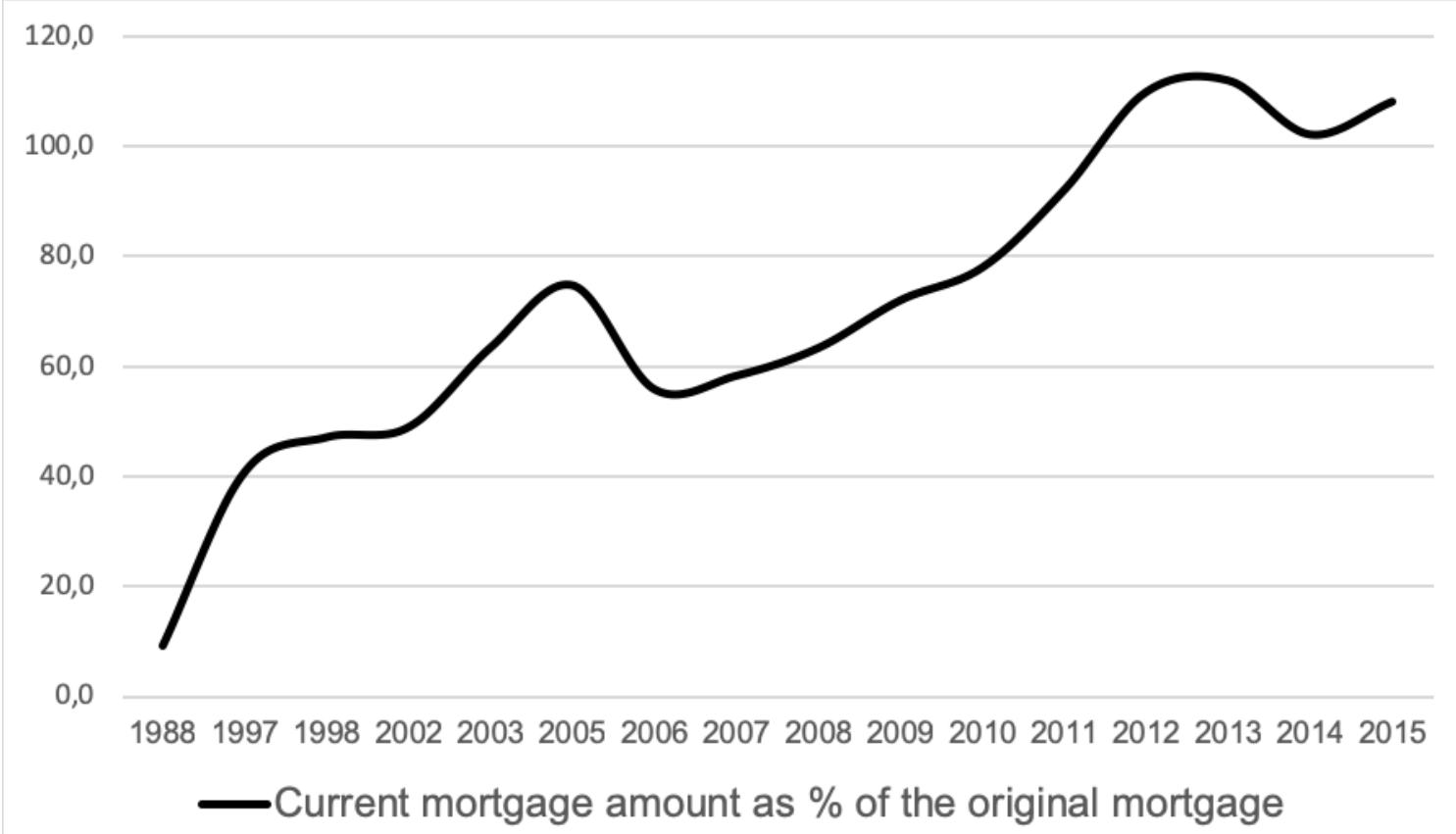

Figure 3: Current mortgage amount as a percentage of the original mortgage amount (source: Author's survey).

Overall, mortgage finance thus appeared to be an important contributor to housing asset building for our sample. It was clear that housing asset creation was indeed taking place and that most of our sample were managing to repay their mortgages, although more recent owners were finding it difficult.

\subsection{The role of education and access to employment}

We mentioned earlier how equal opportunities that became available under the post-apartheid dispensation have helped to create a black middle class. Having obtained a good education, i.e. building human capital, was an important enabling mechanism. Consequently, we assessed our respondents' educational attainments and employment profiles. As regards education, $76.1 \%$ of the respondents had completed Grade 12 and a further $46.1 \%$ had completed some form of tertiary education (diploma, certificate or degree). The higher levels of educational attainment were mostly among interviewees in our sample who had become homeowners in the past ten years. Nearly $75 \%$ of our respondents were employed by the state or by parastatals, both of these indicating good job security. A more important point is that in $91 \%$ of the households at least two people contributed to the household income.

\subsection{Using the house as an asset}

A house can be used as an asset by letting part of it or by selling it and buying or renting a smaller house, or by using it, or part of it, for business premises. Just under $15 \%$ of the respondents said they had extended their houses since first occupying them. On average they had added two extensions, among which were lounges (33\%), bedrooms (30\%), garages $(11 \%)$ and bathrooms $(5 \%)$ or back rooms, the latter usually for letting (3\%). A small percentage either accommodated lodgers or used their house for a home-based business. At least one respondent had added rooms to be used as a shebeen. It was noteworthy that half of the $15 \%$ of the respondents who had made extensions had financed them with their own savings. Approximately a third of the $15 \%$ had had to increase their mortgages, $5 \%$ had used 
the reserve funds on their mortgages and about 3\% had received funding from family members.

In Phase 1 and Phase 2 of Bloemanda, the first areas to make commercial housing available to black households, there are larger numbers of older residents than in the other six suburbs. The responses to a question about their willingness to sell indicated that downsizing was not high on the agenda. Only $9.5 \%$ of the respondents said they would sell their house in two years' time, $9.1 \%$ would do so in three to seven years and only $2.1 \%$ would do so in eight to ten years. There was a general unwillingness to sell, either because of reluctance to downsize and the difficulty of finding an appropriate alternative or because of a desire to leave something substantial to the children. This unwillingness is also understandable given the large place the housing asset occupied in our respondents' asset portfolios.

The low percentage of respondents willing to sell their houses contrasts with the large percentage intending to expand them. Almost a third said they would do so within the next two years and another third in three to seven years. Family and household structure and also life cycles drive the need for expansion and not asset-building intentions. We also found that our respondents' housing assets played a large social role. Approximately $28 \%$ of the respondents had extended households (meaning that at least one person not directly related to the main household also lived in the house). Approximately $35 \%$ of this $28 \%$ said their grandchildren lived with them. This indicates intergenerational value that is not always considered in the literature on asset building.

\subsection{Housing careers and poverty}

Marais et al. (2018) have recently made a detailed study of black middle-class housing careers in South Africa. In the present study we were interested in determining the extent to which housing has been used as a springboard to further housing assets and also the extent of intergenerational transfer. Only $3 \%$ of the respondents had inherited the houses they were living in at the time of the survey. Mortgage finance had been used to finance the purchase in $84 \%$ of the cases. In contrast, as mentioned earlier, only $35 \%$ of the sales of houses in South Africa are financed by a mortgage. Our survey showed that, to create housing assets, members of the black middle class depend heavily on mortgage finance and have little chance of inheriting a house. We found very little evidence that climbing the housing ladder has reduced poverty. The human capital obtained through education has been far more important in this respect (Southall, 2016).

\subsection{Building municipal assets}

Besides providing the black middle class with an opportunity to accumulate further assets, houses are also municipal assets. At the time of the survey, our respondents paid on average 189 ZAR per month for water, 451 ZAR for electricity and 492 ZAR in rates (land-tax levy). However, a large percentage of respondents (about 45\%) did not want to answer the question about rates, though there was less reluctance to answer the questions about payments for water and electricity. We suspect that the municipality does not fully benefit from these housing developments and that there are shortfalls in rates payments. To establish this, more information is required. 


\section{Conclusion}

Our review of the literature on asset-based welfare programmes, which promote homeownership, revealed policy differences between the Global North and the Global South: the former largely emphasises using housing assets to reduce the state's long-term welfare liabilities; the latter is often narrowly focused on titling initiatives and poverty reduction. Our study was intended to link two separate sets of literature: on financial assets and on housing assets.

Apartheid policy encouraged homeownership for whites but banned it for blacks. Homeownership again became available to blacks in South Africa only in the mid-1980s. However, current government policy focuses on the lower end of the black housing market. To date the government Housing Subsidy Programme has enabled about four million families lower-income black families to become homeowners. This achievement is seen as restorative justice after more than 40 years of exclusion from homeownership. For the black middle class there is also an element of restorative justice in owning a house, but more importantly it is social and economic milestone.

Our study investigated three black middle-class housing issues: the role of housing in asset generation, the extent to which housing helps reduce poverty, and the risks associated with asset building. The findings of this exploratory study, using descriptive statistics, largely support the findings of other research (for example Southall, 2016) on the relationship between homeownership, asset building and the black middle class. We found, however, virtually no evidence that black households have indeed used housing as way to escape from poverty. Their housing assets are rather the result of equal opportunities in employment and education. For the black middle class, creating housing assets has been accompanied by risks. Accessing housing finance has been key to purchasing a house. The large percentage of houses in our sample that were bought with a mortgage shows that the black middle class is far more dependent on housing finance than the average South African for property transactions in the market. There had been very few intergenerational transfers. This shows that these households are in an early phase of asset building, one that involves considerable risks. Our research further revealed that, compared with other assets, there is an unhealthy emphasis on housing assets. The more important point here is that asset building should not only have a housing focus. The challenge remains to develop a wider range of assets. But this might only occur over generations.

Olebogeng Litheko, Department of Construction Management, University of the Free State, Bloemfontein, South Africa (LithekoOM@ufs.ac.za)

Lochner Marais, Centre for Development Support, University of the Free State, Bloemfontein, South Africa (MaraisJGL@ufs.ac.za)

Joris Hoekstra, Delft University of Technology, Delft, The Netherlands, and Centre for Development Support, University of the Free State, Bloemfontein, South Africa (J.S.C.M.Hoekstra@tudelft.nl)

Jan Cloete, Centre for Development Support, University of the Free State, Bloemfontein, SouthAfrica (CloeteJS@ufs.ac.za) 
Molefi Lenka, Centre for Development Support, University of the Free State, Bloemfontein, South Africa (LenkaMP@ufs.ac.za)

\section{References}

Al-Umaray, K. (2018) Integrating residential property with private pensions in the EU. Final report. Hamburg, IFF (Institute for Financial Services).

Bourdieu, P. (1986) The forms of capital. In: J. Richardson (ed.) Handbook of Theory and Research for the Sociology of Education, pp. 241-258. Westport, CT, Greenwood.

BusinessTech (2015) A surprising number of SA homeowners are bond free. Available at: https:// businesstech.co.za/news/lifestyle/94083/surprising-number-of-sa-home-owners-are-bond-free/ (accessed 12 May 2018).

Crankshaw, O. (2012) Deindustrialization, professionalization and racial inequality in Cape Town. Urban Affairs Review, 48(6), pp. 836-862. DOI: 10.1177/1078087412451427

De Soto, H. (2000) The mystery of capital: Why capitalism triumphs in the West and fails everywhere else. New York, Basic Books.

Deng, W., Hoekstra, J. \& Elsinga, M. (2017) Redistribution, growth, and inclusion: The development of the urban housing system in China, 1949-2015. Current Urban Studies, 5(4), pp. 423-443. DOI: $10.4236 /$ cus. 2017.54024

Department of Housing (2004) "Breaking new ground": A comprehensive plan for the development of sustainable human settlements. Pretoria.

Department of Human Settlements (2014) Housing programme theory. Pretoria, Department of Human Settlements.

Doling, J. \& Ronald, R. (2010) Home ownership and asset-based welfare. Journal of Housing and the Built Environment, 25, pp. 165-173. DOI: 10.1007/s10901-009-9177-6

Donaldson, R., Mehlomakhulu, T., Darkey, D., Dyssel, M. \& Siyongwana, P. (2013) Relocation: To be or not to be a black diamond in a South African township?. Habitat International, 39, pp. 114-118. DOI: 10.1016/j.habitatint.2012.10.018

Elsinga, M. \& Hoekstra, J. (2015) The Janus face of homeownership-based welfare. Critical Housing Analysis, 2(1), pp. 32-41. DOI: 10.13060/23362839.2015.2.1.174

Gilbert, A. (2002) On the mystery of capital and the myths of Hernando De Soto: What difference does legal title make? International Development Planning Review, 24(1), pp. 1-19. DOI: 10.3828/idpr.24.1.1

Groves, R., Murie, A. \& Watson, C. (2007) Housing and the new welfare state: Perspectives from East Asia and Europe. Aldershot, Ashgate.

Gunter, A. (2013) Creating co-sovereigns through the provision of low cost housing: The case of Johannesburg, South Africa. Habitat International, 39, pp. 278-283. DOI: 10.1016/j.habitatint.2012.10.015

Harrison, P. \& Zack, T. (2014) The wrong side of the mining belt? Spatial transformation and identities in Johannesburg's southern suburbs. In: Harrison, P., Gotz, G., Todes, A. \& Wray, C. (eds.) Changing space, changing city: Johannesburg after apartheid, pp. 269-292. Johannesburg, Wits University Press. DOI: $10.18772 / 22014107656.18$

Hoekstra, J. (2010) Divergence in European welfare and housing systems. Amsterdam, IOS Press.

Krige, D. (2015) "Growing up" and "moving up": Metaphors that legitimise upward social mobility. Development Southern Africa, 32(1), pp. 104-117. DOI: 10.1080/0376835X.2014.975337

Lemanski, C. (2017) Citizens in the middle class: The interstitial policy spaces of South Africa's housing gap. Geoforum, 79, pp. 101-110. DOI: 10.1016/j.geoforum.2016.12.011

Malpass, P. (2008) Housing and the new welfare state: Wobbly pillar or cornerstone? Housing Studies, 23(1), pp. 1-19. DOI: 10.1080/02673030701731100

Marais, L. \& Cloete, J. (2015) Financed homeownership and the economic downturn in South Africa. Habitat International, 50, pp. 261-269. DOI: 10.1016/j.habitatint.2015.08.039

Marais, L. \& Cloete, J. (2017) Housing policy and private sector housing finance: Policy intent and market directions in South Africa. Habitat International, 61, pp. 22-30. DOI: 10.1016/j.habitatint.2017.01.004

Marais, L., Hoekstra, J., Napier, M., Cloete, J. \& Lenka, M. (2018) The housing careers of black middle-class residents in a South African metropolitan area. Journal of Housing and the Built Environment. DOI: $10.1007 / \mathrm{s} 10901-018-9593-6$

Moser, C. (1998) The asset vulnerability framework: Reassessing urban poverty reduction strategies. World Development, 26(1), pp. 1-19. DOI: 10.1016/S0305-750X(97)10015-8

Moser, C. (2006) Asset-based approaches to poverty reduction in a globalized world. Washington, DC, The Brookings Institute. 
Musyoka, J. (2015) Perspectives on emerging wealth distribution in South Africa's previously disadvantaged households: A systems thinking approach. Doctoral thesis. Durban, University of KwaZulu-Natal.

National Credit Regulator (2016) Consumer credit market report. Johannesburg, National Credit Regulator.

Nussbaum, M. (2003) Capabilities as fundamental entitlements: Sen and social justice. Feminist Economics, 9(2/3), pp. 33-59. DOI: 10.1080/1354570022000077926

Payne, G., Durand-Lasserve, A., Rakodi, C. \& Marx, C. (2008) Social and economic impacts of land titling programmes in urban and peri-urban areas: International experience and case studies of Senegal and South Africa. Johannesburg, Global Land Tool Network and University of Witwatersrand.

Piketty, T. (2014) Capital in the twentieth century. Cambridge, MA, The Belknap Press of Harvard University. DOI: $10.4159 / 9780674369542$

Prabhakar, R. (2018) A house divided: Asset-based welfare and housing asset-based welfare. International Journal of Housing Policy. DOI: 10.1080/19491247.2018.1441008

Rakodi, C. (1999) A capital assets framework for analysing household livelihood strategies: Implications for policy. Development Policy Review, 17(3), pp. 315-342. DOI: 10.1111/1467-7679.00090

Royston, L. (2006) Barking dogs and building bridges: A contribution to making sense of de Soto's ideas in the South African context. In: Huchzermeyer, M. \& Karam, A. (eds.) Informal settlements: A perpetual challenge?, pp. 165-179. Cape Town, UCT Press.

Sen, A. (1992) Inequality re-examined. Oxford, Oxford University Press.

Sherraden, M. (2003) Assets and the social investment state. In: Paxton, W. (ed.) Equal shares: building a progressive and coherent asset based welfare strategy, pp. 28-41. London, IPPR (Institute for Public Policy Research).

South African Institute of Race Relations (2012) South African Survey 2010/11. Johannesburg, SAIRR.

Southall, R. (2016) The new black middle class in South Africa. Johannesburg, Jacana Media.

StatsSA. (2013) Census data, 2011. Pretoria.

Tomlinson, M. (1997). Mortgage bondage? Financial institutions and low-cost housing delivery. Johannesburg, Centre for Policy Studies Research Report.

Tomlinson, M. (2007) The development of a low-income housing finance sector in South Africa: Have we finally found a way forward? Habitat International, 31(1), pp. 77-86. DOI: 10.1016/j.habitatint.2006.04.004 